NATIONAL LABORATORY

\title{
The Application of Traits-Based Assessment Approaches to Estimate the Effects of Hydroelectric Turbine Passage on Fish Populations
}

\section{April 2012}

Prepared by

Glenn F. Čada and Peter E. Schweizer

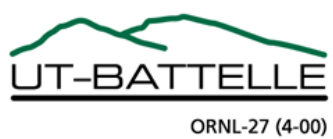




\title{
DOCUMENT AVAILABILITY
}

Reports produced after January 1, 1996, are generally available free via the U.S. Department of Energy (DOE) Information Bridge.

Web site http://www.osti.gov/bridge

Reports produced before January 1, 1996, may be purchased by members of the public from the following source.

\author{
National Technical Information Service \\ 5285 Port Royal Road \\ Springfield, VA 22161 \\ Telephone 703-605-6000 (1-800-553-6847) \\ TDD 703-487-4639 \\ Fax 703-605-6900 \\ E-mail info@ntis.gov \\ Web site http://www.ntis.gov/support/ordernowabout.htm
}

Reports are available to DOE employees, DOE contractors, Energy Technology Data Exchange (ETDE) representatives, and International Nuclear Information System (INIS) representatives from the following source.

Office of Scientific and Technical Information

P.O. Box 62

Oak Ridge, TN 37831

Telephone 865-576-8401

Fax 865-576-5728

E-mail reports@osti.gov

Web site http://www.osti.gov/contact.html

This report was prepared as an account of work sponsored by an agency of the United States Government. Neither the United States Government nor any agency thereof, nor any of their employees, makes any warranty, express or implied, or assumes any legal liability or responsibility for the accuracy, completeness, or usefulness of any information, apparatus, product, or process disclosed, or represents that its use would not infringe privately owned rights. Reference herein to any specific commercial product, process, or service by trade name, trademark, manufacturer, or otherwise, does not necessarily constitute or imply its endorsement, recommendation, or favoring by the United States Government or any agency thereof. The views and opinions of authors expressed herein do not necessarily state or reflect those of the United States Government or any agency thereof. 


\title{
THE APPLICATION OF TRAITS-BASED ASSESSMENT APPROACHES TO ESTIMATE THE EFFECTS OF HYDROELECTRIC TURBINE PASSAGE ON FISH POPULATIONS
}

\author{
G. F. Čada \\ P. E. Schweizer
}

Date Published: April 2012

\author{
Prepared for the \\ Water Power Program \\ Office of Energy Efficiency and Renewable Energy \\ U.S. Department of Energy \\ Washington, DC \\ Prepared by \\ OAK RIDGE NATIONAL LABORATORY \\ Oak Ridge, Tennessee 37831-6283 \\ managed by \\ UT-BATTELLE, LLC \\ for the \\ U.S. DEPARTMENT OF ENERGY \\ under contract DE-AC05-00OR22725
}





\section{CONTENTS}

Page

List of Figures. ..v

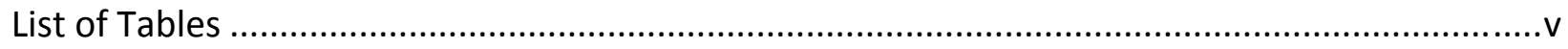

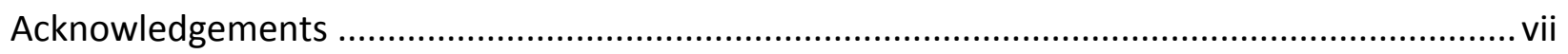

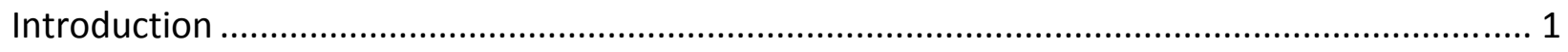

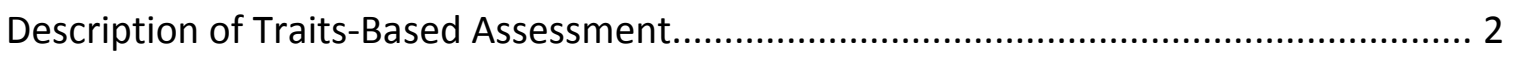

Application of TBA to Hydropower Effects on Fish ....................................................... 5

1. Exposure (Susceptibility) to Turbine Passage ..................................................... 5

2. Intrinsic Sensitivity to a Turbine Passage Stressors ............................................. 9

Intrinsic Sensitivity to a Turbine Passage Stressor - Influence of Swim Bladder Morphology on the Response to Pressure Changes.......................................... 9

Intrinsic Sensitivity to a Turbine Passage Stressor - Influence of Fish Size on the

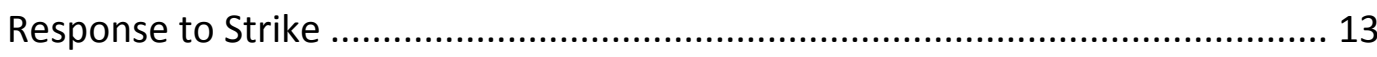

Intrinsic Sensitivity to a Turbine Passage Stressor - Influence of Integument on the Response to Abrasion .......................................................................... 13

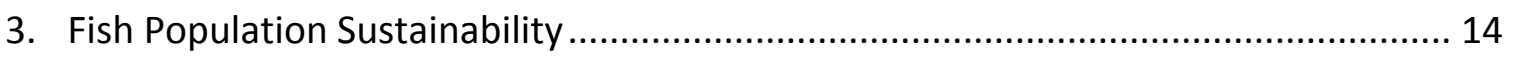

Fish Population Sustainability - Effects of Demography ................................ 14

Fish Population Sustainability - Influence of Recolonization ........................... 16

Cluster Analysis of Riverine Fish Species for a Traits-Based Assessment.............................. 17

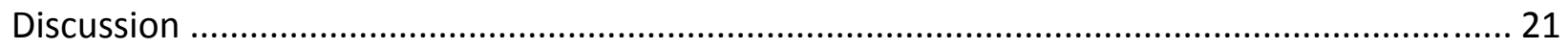

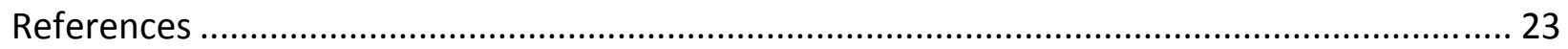





\section{LIST OF FIGURES}

Figure

Page

1. The relationships between trait distributions, performance filters, and consequent community structure/ecosystem function.

2. Fish species traits that influence the risk of turbine passage losses at hydroelectric power plants. .6

3. Cluster analysis of 94 freshwater fish species based on 9 traits 18

4. Ordination of 9 traits for 94 species of freshwater fishes using non-metric multidimensional scaling

\section{LIST OF TABLES}

1. Criteria and categories used by Welcomme et al. (2006) to describe fish environmental guilds

2. Examples of fish traits that have bearing on susceptibility to entrainment in hydroelectric turbines and the mechanistic linkage between entrainment susceptibility and fish trait .......9

3. Examples of fish traits that have bearing on turbine passage survival and the mechanistic linkage between turbine-passage stressor and fish trait

4. Examples of fish traits that have bearing on reservoir passage and the mechanistic linkage between reservoir passage and fish trait. 



\section{ACKNOWLEDGEMENTS}

We thank T. J. Heibel for his valuable comments on an earlier manuscript. This research was supported by the U.S. Department of Energy's (DOE) Office of Energy Efficiency and Renewable Energy, Water Power Program. Oak Ridge National Laboratory is managed by UT-Battelle, LLC, for the DOE under contract DE-AC05-000R22725. 



\section{Introduction}

One of the most important environmental issues facing the hydropower industry is the adverse impact of hydroelectric projects on downstream fish passage. Fish that migrate long distances as part of their life cycle include not only important diadromous species (such as salmon, shads, and eels) but also strictly freshwater species. The hydropower reservoirs that downstream-moving fish encounter differ greatly from free-flowing rivers. Many of the environmental changes that occur in a reservoir (altered water temperature and transparency, decreased flow velocities, increased predation) can reduce survival. Upon reaching the dam, downstream-migrating fish may suffer increased mortality as they pass through the turbines, spillways and other bypasses, or turbulent tailraces. Downstream from the dam, insufficient environmental flow releases may slow downstream fish passage rates or decrease survival.

There is a need to refine our understanding of the relative importance of causative factors that contribute to turbine passage mortality (e.g., strike, pressure changes, turbulence) so that turbine design efforts can focus on mitigating the most damaging components. Further, present knowledge of the effectiveness of turbine improvements is based on studies of only a few species (mainly salmon and American shad). These data may not be representative of turbine passage effects for the hundreds of other fish species that are susceptible to downstream passage at hydroelectric projects. For example, there are over 900 species of fish in the United States. In Brazil there are an estimated 3,000 freshwater fish species, of which $30 \%$ are believed to be migratory (Viana et al. 2011). Worldwide, there are some 14,000 freshwater fish species (Magurran 2009), of which significant numbers are susceptible to hydropower impacts. By comparison, in a compilation of fish entrainment and turbine survival studies from over 100 hydroelectric projects in the United States, Winchell et al. (2000) found useful turbine passage survival data for only 30 species. Tests of advanced hydropower turbines have been limited to seven species - Chinook and coho salmon, rainbow trout, alewife, eel, smallmouth bass, and white sturgeon.

We are investigating possible approaches for extending experimental results from the few tested fish species to predict turbine passage survival of other, untested species (Čada and Richmond 2011). In this report, we define the causes of injury and mortality to fish tested in laboratory and field studies, based on fish body shape and size, internal and external morphology, and physiology. We have begun to group the large numbers of unstudied species into a small number of categories, e.g., based on phylogenetic relationships or ecological similarities (guilds), so that subsequent studies of a few representative species (potentially including species-specific Biological Index Testing) would yield useful information about the overall fish community. This initial effort focused on modifying approaches that are used in the environmental toxicology field to estimate the toxicity of substances to untested species. Such techniques as the development of species sensitivity distributions (SSDs) and Interspecies Correlation Estimation (ICE) models rely on a considerable amount of data to establish the speciestoxicity relationships that can be extended to other organisms. There are far fewer studies of turbine passage stresses from which to derive the turbine passage equivalent of $\mathrm{LC}_{50}$ values. Whereas the SSD and ICE approaches are useful analogues to predicting turbine passage injury and mortality, too few 
data are available to support their application without some form of modification or simplification. In this report we explore the potential application of a newer, related technique, the Traits-Based Assessment (TBA), to the prediction of downstream passage mortality at hydropower projects.

\section{Description of Traits-Based Assessment}

In the last decade there has been growing interest in basing biological assessments or ecological risk analyses on organisms' traits rather than on their taxonomy. Traits are measureable properties of an organism, such as body size and shape, longevity, or feeding guild (Baird et al. 2008; Culp et al. 2010). Organism and/or species traits are valuable to risk assessors because they can include a wide variety of morphological, physiological, behavioral, and life history characteristics, some of which influence the animal's susceptibility to stressors. For example, the chance of an organism being exposed to a toxic chemical is often better explained by its behavior than by its position on the family tree. Once exposed, traits such as the types and levels of detoxification enzymes will have a greater influence on survival than taxonomic relationships (although closely related organisms will often share similar traits). Vieira et al. (2006) distinguished between biological traits and ecological traits. In their scheme, biological traits include morphological, physiological, and life history characteristics, whereas ecological traits include environmental preferences and behaviors. This distinction may be relevant to a consideration of hydropower impacts on fish species; biological traits may be influential in determining injuries and survival of turbine-passed fish, while environmental preferences and behavioral (ecological) traits may influence the susceptibility of fish to turbine passage in the first place.

Rubach et al. (2010) described a broad framework for applying a TBA to ecotoxicology studies and ecological risk assessments. They pointed out that ecological and physiological factors are important in determining vulnerability to chemicals, and incorporation of such traits into ecological risk assessments might permit a better prediction of potential adverse effects to a broader range of species. In a more general sense, there is a mechanistic relationship or linkage between a stressor and a trait. The performance of a trait is an expression of its fitness in a given environment; conversely, the environment acts as a "performance filter" to eliminate traits with inadequate fitness (Webb et al. 2010).

Webb et al. (2010) provide a conceptual framework for describing the relationship between an existing distribution of species traits, performance filters that alter the distribution of those traits, and the consequent effects on community structure and ecosystem function (Figure 1). In their framework, the functional trait distribution is drawn from the contributing pool of individuals. The functional trait distribution is altered (filtered) by the environment based on performance via natural selection and/or a mechanistic relationship between stressor and trait at a particular location or time. In this hypothetical example, the performance filter favors individuals with higher values of the trait and the resulting filtered trait distribution is shifted towards higher trait values (Webb et al. 2010). The filtered trait distribution can then be used to predict changes in either ecosystem function or species composition and abundance. Applying this construct to a hydropower reservoir, the initial functional trait distribution (top of Figure 1) might be the size (length) of fish in the reservoir. The performance filter 


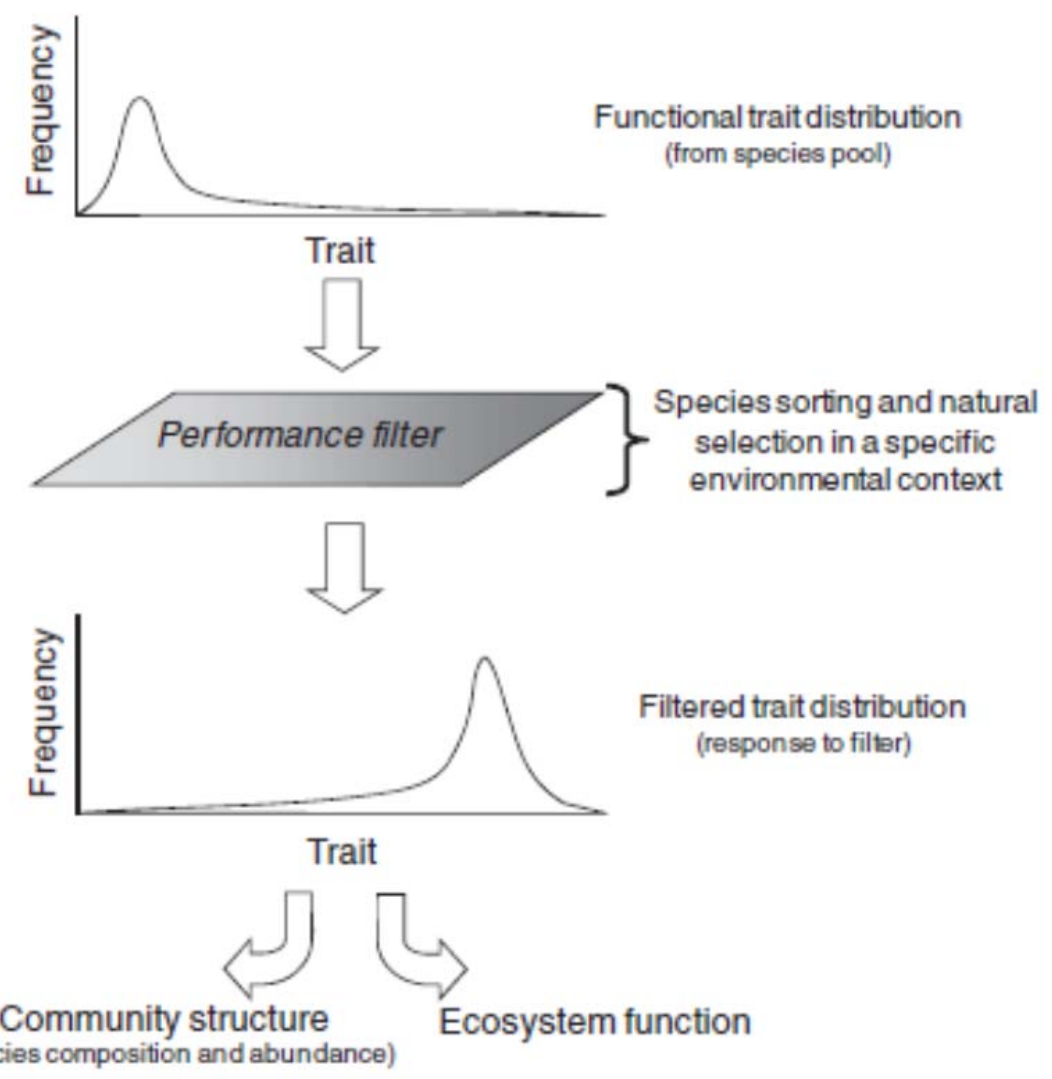

Figure 1. The relationships between trait distributions, performance filters, and consequent community structure/ecosystem function.

From Webb et al. (2010).

might be turbine entrainment, which often has a greater effect on small, slow-swimming fish species than on larger fish that are able to avoid being entrained in the intake flow. The result of differential turbine entrainment effects is a filtered trait distribution of large fish (both individuals and species) remaining in the reservoir because smaller fish have been transported out of the reservoir through turbine passage. The changes in fish species and size distribution brought about by this performance filter could have consequences to ecosystem function in the reservoir.

Other mechanistic relationships (linkages) can be identified between aspects of hydropower operations (stressors) and fish traits. Elaboration of the TBA method in the context of downstream passage-related stressors can provide a framework for evaluating the sensitivity of untested fish species to hydropower turbine passage and biological performance testing of existing and advanced turbines. 


\section{Application of TBA to Hydropower Effects on Fish}

TBA has mainly been discussed in the context of ecotoxicology studies and ecological risk assessments related to toxicants and such large scale effects as climate change (Poff et al. 2010). However, the TBA approach may have value for predicting the impacts of hydropower operations on fish. For example, there is a growing body of literature that suggests that rapid and extreme pressure decreases that occur during turbine passage are damaging to fish, owing to the rapid expansion of the swim bladder associated with the decompression on the downstream side of the runner (Abernethy et al. 2001; Čada et al. 2001; Brown et al. 2009). Swim bladder expansion under low pressures is likely to be less damaging to those fish that have a pneumatic duct that can vent the expanding gases inside of the swim bladder. Hence, the presence or absence of a pneumatic duct is a morphological trait that has utility in assessing the risk of injury or mortality resulting from turbine passage. An intrinsic sensitivity to turbine passage stressors, such as fish species without pneumatic ducts, will make their individuals (and populations) more vulnerable to turbine passage (Figure 2). This intrinsic sensitivity is less important if the species is not migratory and/or occupies habitats that are far from the turbine intake; in this case, turbine passage and consequent effects on the population are unlikely.

The following sections describe stressors associated with hydropower projects, fish traits relevant to assessing the impacts of those stressors, and the mechanistic relationships (linkages) between stressors and traits. The emphasis is on turbine passage survival, although traits and linkages relevant to reservoir passage and susceptibility to turbine entrainment are also discussed (Figure 2).

\section{Exposure (Susceptibility) to Turbine Passage}

The likelihood of turbine passage is affected by at least three traits: migratory habits, habitat choices, and behavior. Fish species that do not migrate (i.e., exhibit only localized movements), that occupy shallow-water, shoreline habitats or floodplain water bodies, are averse to the structures and acoustic stimuli (noises) associated with dams, and/or are strong swimmers are less likely to be entrained in a hydropower turbine intake flow than are species without these characteristics.

Some species must travel between freshwater and the ocean as part of their lifecycle (diadromy) or move long distances within a river for reproduction or other life history requirements (potamodromy). Hence, the preservation of diadromous and potamodromous (migratory) species may require both upstream and downstream passage measures when mainstem dams pose a barrier to movements. Migratory species will be exposed to turbine passage at least once during their lifecycle (e.g., downstream migrating juvenile Pacific salmon), and for some species both juveniles and post-spawning adults may move downstream through the hydroelectric turbines (e.g., juvenile and adult American shad and Atlantic salmon).

On the other hand, many species of freshwater fish move only short distances within a river or reservoir throughout their lifecycle. These resident species are not necessarily exposed to turbine passage, particularly if they occupy shoreline habitats in the upper portions of reservoirs. Fish that reside in the 


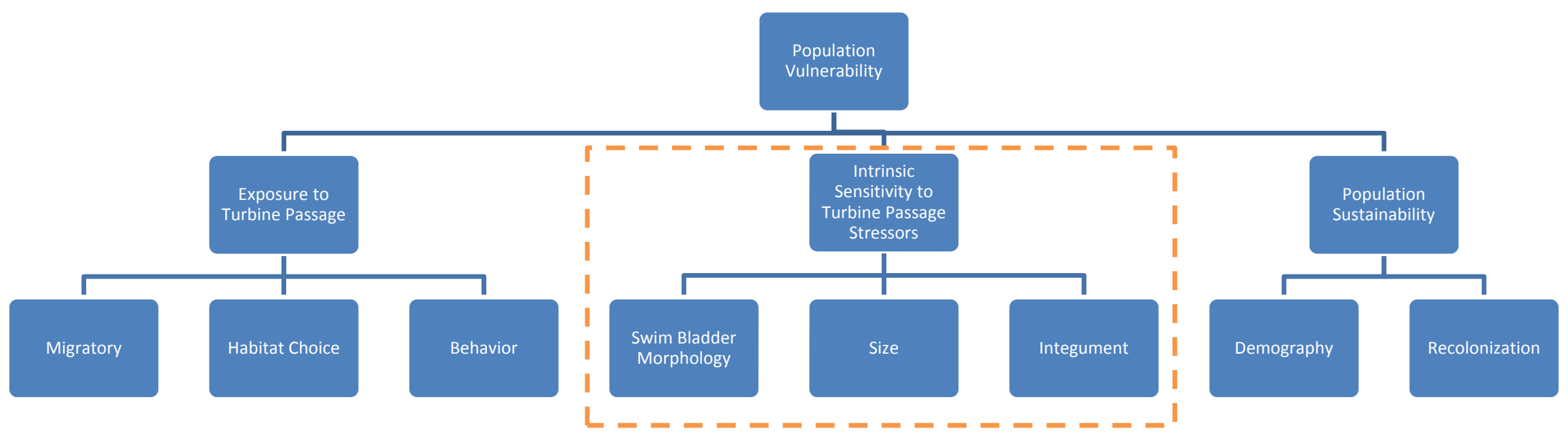

Figure 2. Fish species traits that influence the risk of turbine passage losses at hydroelectric power plants.

The area within the dashed lines considers traits that are relevant to improvements in turbine design and operation.

Modified from Rubach et al. (2010). 
open reservoir may prefer the reservoir bottom (e.g., catfish) or the pelagic zone (e.g., gizzard shad); depending on the location of the turbine intakes, resident fish in these zones may be more or less vulnerable to being entrained in the turbine intake flows. Turbine entrainment and consequent exposure to turbine passage stressors, then, is related to a fish species' reproductive/migratory life cycle requirements, habitat choices, and behavior.

In the absence of site-specific studies, an evaluation of the susceptibility of various members of the fish community to turbine passage could be adapted from a consideration of environmental guilds. Environmental guilds combine the members of a fish community into categories based on behavior or responses to environmental variations (Leonard and Orth 1988; Austen et al. 1994). For example, as an approach to assessing the health of rivers Noble et al. (2007) categorized European fish species into a number of guilds, including a migration guild (long migratory anadromous, long migratory catadromous, and intermediate distance migrations within a river). Fish species in the first two groups in this guild, reflecting long-distance diadromy, would be especially susceptible to turbine passage, compared to resident species.

Welcomme et al. (2006) defined a number of fish environmental guilds based on their location in a river system, migration and movement patterns, reproductive strategy, and resistance to anoxia (Table 1). The guilds of Welcomme et al. (2006) were originally developed to categorize fish responses to changes in river flows; however, the life cycles, behaviors, and habitat preferences of fish species in the various categories within each of the criteria also give an indication of the susceptibility (+) or resistance (-) to turbine entrainment of fish species that exhibit those characteristics. Fish that occupy the main channel of a river, for example, are more likely to be entrained in hydropower turbines than fish that are characteristic of floodplain pools disconnected from the main river. Fish species that are sensitive to low dissolved oxygen concentrations are more likely to be found in surface waters of the river channel (where they may be entrained in the turbine intake flows) than are fish species that are tolerant of anoxia (and often found in shallow, stagnant floodplain pools and wetlands). Welcomme et al. (2006) pointed out that in regard to flow responses, many species are flexible in their movements/migrations, behaviors, and habitat requirements and may complicate this general classification scheme by appearing in more than one guild. Similarly, this flexibility could affect the susceptibility to turbine entrainment in particular settings. Non-migratory fish in a reservoir may still encounter the turbine intake; in this case, swim speed, which is often directly related to size, may be important for avoiding entrainment in the intake flow (Table 2).

The responses of large river fish assemblages to human disturbance and the role of floodplain water bodies were considered by de Leeuw et al. (2007). They noted that rheophilic and diadromous species are more sensitive to upstream and downstream migration barriers than are limnophilic (pond or lake) species. Limnophilic fish species prefer floodplain water body habitats like side channels, connected oxbow lakes, and isolated floodplain lakes; such species are unlikely to encounter hydropower turbine intakes in their preferred habitats. Hence, the relative susceptibility to turbine passage may be initially assessed by categorizing the fish community into migratory, rheophilic, and limnophilic species (Grift et al. 2006; de Leeuw et al. 2007). 
Table 1. Criteria and categories used by Welcomme et al. (2006) to describe fish environmental guilds. Characteristics that lead to membership in a guild may make a fish species relatively more $(+)$ or less (-) susceptible to turbine passage.

\begin{tabular}{|c|c|c|}
\hline Criterion & Categories within the Criterion & $\begin{array}{l}\text { Potential } \\
\text { susceptibility to } \\
\text { turbine passage } \\
\text { (+ or }- \text { ) }\end{array}$ \\
\hline $\begin{array}{l}\text { Location in a river } \\
\text { system }\end{array}$ & $\begin{array}{l}\text { Main channel } \\
\text { Seasonal anabranches and backwaters } \\
\text { Floodplain pools seasonally connected to } \\
\text { main river } \\
\text { Floodplain pools disconnected from the } \\
\text { main river } \\
\text { Floodplain }\end{array}$ & $\begin{array}{l}+ \\
- \\
- \\
- \\
-\end{array}$ \\
\hline $\begin{array}{l}\text { Migration and } \\
\text { movement }\end{array}$ & $\begin{array}{l}\text { Longitudinal migrations } \\
\text { Lateral migrations } \\
\text { Seasonal lateral movements } \\
\text { Drift }\end{array}$ & $\begin{array}{l}+ \\
- \\
- \\
+\end{array}$ \\
\hline $\begin{array}{l}\text { Reproductive } \\
\text { strategy (after } \\
\text { Balon 1975, 1990) }\end{array}$ & $\begin{array}{l}\text { Non-guarders } \\
\text { Guarders } \\
\text { Bearers }\end{array}$ & $\begin{array}{l}+ \\
-\end{array}$ \\
\hline $\begin{array}{l}\text { Resistance to } \\
\text { anoxia }\end{array}$ & $\begin{array}{l}\text { Not resistant to low dissolved oxygen } \\
\text { concentrations } \\
\text { Tolerant of low dissolved oxygen } \\
\text { concentrations }\end{array}$ & $\begin{array}{l}+ \\
-\end{array}$ \\
\hline
\end{tabular}


Table 2. Examples of fish traits that have bearing on susceptibility to entrainment in hydroelectric turbines and the mechanistic linkage between entrainment susceptibility and fish trait.

\begin{tabular}{c|c|c}
\hline Trait & Definition & Entrainment Stressor-Trait Linkage \\
\hline Migration & $\begin{array}{c}\text { Fish are either (1) non-migratory } \\
\text { residents in the reservoir or stream } \\
\text { reach or (2) migrate long distances for } \\
\text { feeding or reproduction (diadromy or } \\
\text { potadromy) }\end{array}$ & Categorical \\
\hline Swim speed & $\begin{array}{c}\text { The maximum speed at which a fish can } \\
\text { move for several seconds (burst speed) }\end{array}$ & Continuous \\
\hline
\end{tabular}

Information about ecological and biological traits of freshwater fishes can be accessed from the Fish Traits database (Frimpong and Angermeier 2009). These authors compiled data about trophic ecology, body size, reproductive ecology, life history, and habitat preferences for 809 fish species found in freshwaters of the conterminous United States. Some of these traits may be valuable for assessing the likelihood of a particular species being entrained in hydropower turbine intake flows and the consequent injury or mortality. FishBase (Froese and Pauly 2011) is a relational database with data for over 28,500 species of fish worldwide. Depending on the species, FishBase contains information about morphology, ecology, diet, and reproduction, some of which may be useful for assessing downstream passage effects.

\section{Intrinsic Sensitivity to Turbine Passage Stressors}

Some turbine passage fish survival studies have attempted not only to quantify the mortality among turbine-passed fish, but also to ascertain the particular causes of that mortality. Turbine passage stressors include strike by runner blades and other obstructions, pressure changes, shear stresses, and turbulence (Čada et al. 1997). The following sections describe how particular traits of fish (swim bladder morphology, fish size, and integument type; Figure 2) may make them more or less sensitive to these stress mechanisms.

Intrinsic Sensitivity to a Turbine Passage Stressor - Influence of Swim Bladder Morphology on the Response to Pressure Changes

Description of Stressor - Water pressure is expressed in kilopascals ( $\mathrm{kPa})$, where $101.3 \mathrm{kPa}=1$ atmosphere $=760 \mathrm{~mm} \mathrm{Hg}=14.73 \mathrm{psi}$. Water pressure increases with depth at a rate of $9.799 \mathrm{kPa} / \mathrm{m}$. Thus, a fish residing at the water surface experiences about $101 \mathrm{kPa}$, whereas a fish residing at $10 \mathrm{~m}$ 
depth experiences a water pressure of about $200 \mathrm{kPa}$. Because fish can control their depth, they can ensure that the rate of pressure change they experience in natural rivers is small and not damaging.

Surface-acclimated fish that are entrained in the turbine flow experience increasing water pressures as they descend to the upstream side of the runner. This period of pressure increase may occur in a time frame measured in seconds to minutes, depending on whether the fish resists entrainment by swimming against the flow in the forebay and intake. As the fish passes through the runner, pressure drops very rapidly on the downstream side of the runner and into the draft tube, often to less than atmospheric pressure. Occasionally, pressures downstream from the runner may momentarily drop below the vapor pressure of water, resulting in cavitation. Passage through this low pressure zone occurs in no more than a few seconds. After leaving the draft tube, the fish is again exposed to near atmospheric pressures at the surface of the tailrace or greater pressures if the fish swims to deeper water.

Čada (1990) reported that water pressures in one bulb turbine (horizontal propeller-type turbine) varied from a high of $210 \mathrm{kPa}$ to a low of about $80 \mathrm{kPa}$. In such a turbine, a surface-acclimated fish (101 kPa) would experience a doubling of pressure upstream from the runner, followed by a momentary pressure decrease to about $80 \%$ of the acclimation pressure, all within as little as 15 seconds.

Bell (1991) calculated pressures near the Francis runners at the Lequille, Cushman No. 2, and Shasta Hydroelectric plants. Between the turbine entrance (i.e., leading edge of the runner blades, at midheight of the wicket gates) to the bottom of the turbine (entrance to the draft tube), the estimated pressures dropped from 582 to $56 \mathrm{kPa}$ at Lequille, from 830 to $68 \mathrm{kPa}$ at Cushman No. 2, and from 736 to $95 \mathrm{kPa}$ at the Shasta Hydroelectric Plant.

Calculated pressures experienced by fish passing through a Kaplan turbine at the McNary Dam on the Columbia River would be as high as $460 \mathrm{kPa}$ (Watson 1995). A fish passing along the upper surface of the turbine blade near the hub would be exposed to pressures that are estimated to be no lower than $115 \mathrm{kPa}$. The most damaging pressure changes would be experienced by fish entering at the ceiling depth and passing along the bottom side of the blade near its tip; in this case, estimated pressures would drop from $340 \mathrm{kPa}$ to $2 \mathrm{kPa}$ in less than one second. A value of $2 \mathrm{kPa}$ is approximately the vapor pressure of water, i.e., the pressure at which cavitation occurs. Exposure to the lowest pressures, on the downstream side of the runner, were estimated to last no more than 0.25 seconds before pressure rapidly returned to near atmospheric pressures in the draft tube and tailwaters.

Čada et al. (1997) reviewed a large number of experiments that examined the effects of pressure increases and decreases on fish. They concluded that pressure increases of the magnitude found in hydroelectric turbines are unlikely to injure or kill entrained fish. Rapid, brief pressure increases caused little or no direct mortality in a variety of studies using a variety of fish. However, high pressures may alter the behavior of fish such that they may have increased susceptibility to other, non-pressure-related sources of mortality. Some investigators have noted that fish exposed to high pressures were momentarily stunned. Although the test fish fully recovered in the laboratory holding tanks, temporarily stunned fish may be more susceptible to predators in the tailwaters of a hydroelectric dam. 
The pressure decreases that fish experience downstream from the runner occur rapidly and may be large. From a direct mortality standpoint, laboratory studies suggest that the brief exposure to subatmospheric pressures within the turbine is more likely to be damaging to fish with swim bladders. Although there is considerable variation in the response of fish to pressure reductions, the highest mortalities occurred when the pressure reduction was greatest, i.e., when the exposure pressure was a relatively small fraction of the acclimation pressure. On the other hand, three tests in which exposure pressure was no less than $60 \%$ of the acclimation pressure resulted in little or no mortality.

Fish Trait related to Turbine Passage Pressure Changes: Swim Bladder Morphology - Among fish with swim bladders, the response to rapid pressure changes encountered within a turbine is affected by whether the fish is physostomous or physoclistous. Physostomous fish have a pneumatic duct which connects the swim bladder with the esophagus. Gas can be quickly taken into or vented from the swim bladder through the mouth and pneumatic duct, so that adjustment to changing water pressures can take place rapidly, often on the order of seconds. As a general rule, physostomes include the soft-rayed fishes like salmon, trout, catfish, minnows, shad, and gar. On the other hand, physoclists lack a direct connection between the swim bladder and the esophagus. In these fish, the contents and pressures within the swim bladder must be adjusted by diffusion into the blood, a process measured on the order of hours. Physoclistous fish include many of the spiny-rayed fishes such as perch, bass, and bluegill sunfish.

Once inside a turbine, surface-acclimated physoclistous fish cannot adjust the volume of their swim bladder rapidly enough to compensate for changing water pressures; the swim bladder will be compressed and the fish will become more dense under increasing water pressures. Conversely, in a region of low pressure, downstream from the runner, the swim bladder will expand rapidly, potentially to the point of bursting. Physostomes have more control over the volume of gas in the swim bladder than physoclists. If a deep-water-adapted physostome is drawn toward a surface intake, decreasing water pressure will cause the swim bladder to expand. Excess gas can be vented through the pneumatic duct if the rate of ascent is sufficiently slow. However, even physostomous fish may not be capable of venting excess gas in response to the rapid pressure reductions (often less than $1 \mathrm{sec}$ ) that occur within the turbine and draft tube.

As noted, from a direct mortality standpoint, laboratory studies suggest that the brief exposure to pressure decreases (potentially down to subatmospheric pressures) within the turbine are more damaging to fish than pressure increases. Decompression may damage the swim bladder owing to its rapid and extreme expansion, and may cause gas emboli to form in body tissues and the blood stream. Whereas embolism formation is a physical phenomenon that is likely to affect most fish equally, injuries from swim bladder expansion may be less for physostomous fish (that can vent the rapidly expanding gas) than for physoclists.

Although Čada et al. (1997) noted that there is considerable variation in the response of fish to pressure reductions, the highest mortalities occurred when the pressure reduction was greatest, i.e., when the exposure pressure was a relatively small fraction of the acclimation pressure. On the other hand, three 
tests in which exposure pressure was no less than $60 \%$ of the acclimation pressure resulted in little or no mortality.

Based on these limited studies of a variety of fish, Čada et al. (1997) suggested that pressures within the turbine should fall to no less than $60 \%$ of the value to which entrained fish are acclimated. For surfaceoriented fish, a pressure of $60 \mathrm{kPa}$ or greater at all points within the turbine and draft tube would be expected to protect most fish from direct mortality resulting from low pressures.

Based on a consideration of salmonid data in Bell (1991), ARL (1996) suggested that minimum pressures within the turbine be no less than $30 \%$ of the fish's initial acclimation pressure. For fish distributed within the top $34 \mathrm{ft}$ of water, this would dictate a minimum pressure of about $10 \mathrm{psi}$ (69 $\mathrm{kPa})$. ARL's suggested minimum pressure criterion ( $30 \%$ of acclimation) is less restrictive than the "60 percent of acclimation" criterion suggested by Čada et al. (1997). Whereas it may protect deep-adapted salmonids (and other physostomes) that are able to vent some of the expanding gases in the swim bladder as they are drawn upwards toward the intake, the $30 \%$ criterion may not be sufficient to protect other species of physoclistous fish.

Whatever safe pressure drop criterion is appropriate to protect the majority of fish, swim bladder morphology (i.e., physostomous vs. physoclistous) is a useful discrete variable for estimating the effects of turbine-passage-related pressure decreases on untested fish species (Table 3).

Table 3. Examples of fish traits that have bearing on turbine passage survival and the mechanistic linkage between turbine-passage stressor and fish trait.

\begin{tabular}{|c|c|c|}
\hline Trait & Description & Turbine Passage Stressor-Trait Linkage \\
\hline $\begin{array}{l}\text { Swim bladder } \\
\text { morphology }\end{array}$ & $\begin{array}{l}\text { The swim bladder can be rapidly filled or } \\
\text { emptied by means of the pneumatic } \\
\text { duct (physostomous) or can only be } \\
\text { slowly filled/emptied by diffusion } \\
\text { (physoclistous) }\end{array}$ & $\begin{array}{l}\text { Rapid decompression that occurs } \\
\text { downstream from the turbine runner may } \\
\text { cause damaging expansion of the swim } \\
\text { bladder unless the expanding gases can be } \\
\text { vented through the pneumatic duct }\end{array}$ \\
\hline Size & Total length (TL) & $\begin{array}{l}\text { Large (long) fish are more likely than small } \\
\text { fish to be struck while passing through the } \\
\text { space between the rotor blades }\end{array}$ \\
\hline Integument & $\begin{array}{l}\text { Thickness of protective mucous coating } \\
\text { on surface of the fish and/or the } \\
\text { resistance of scales to being dislodged }\end{array}$ & $\begin{array}{l}\text { Abrasion from contact with hard } \\
\text { structures or fluid forces (shear stresses) } \\
\text { can cause loss of protective mucous } \\
\text { coating, descaling, or damage to the skin }\end{array}$ \\
\hline
\end{tabular}




\section{Intrinsic Sensitivity to a Turbine Passage Stressor - Influence of Fish Size on the Response to Strike}

Description of Stressor - Fish entrained in the flow passing through the turbine may contact the moving runner blades and a variety of fixed structures. Fixed structures include the walls of the turbine passage, wicket gates and stay vanes upstream from the runner, and draft tube support piers downstream from the runner. Contact may range from a high-speed collision with a structure at an angle normal to the path of the moving fish (strike) to glancing, low force contacts with a structure that is largely parallel to the path of the fish. For simplicity, we term the former effect strike and the latter abrasion.

Fish Trait related to Turbine Passage Strike: Size - Turbine runners vary in the number of blades, shape of blades, and rate of rotation. Some runners have a small number of blades with large inter-blade spaces and a relatively slow rate of rotation (e.g., large Kaplan turbines). Other turbine types have runners with closely spaced blades that rotate rapidly (e.g., Francis and Pelton turbines); it is difficult for a large fish to pass through such runners without contacting the blade. For a given turbine design, the size of a fish, or more specifically its length, is directly related to the chance that it will strike a fixed or moving structure (runner) during turbine passage.

Beginning with von Raben (1957) and Monten (1985), a variety of models have been used to predict the survival of fish through turbines of different designs and operating characteristics (see reviews of Turnpenny et al. 1992; Čada et al. 1997; and Deng et al. 2005). Fish length is always a biological variable in equations used to predict strike, although Deng et al. (2005) pointed out that other important biological factors include mass, stiffness, and probability of tissue damage from a strike of a given force. All of these morphological characteristics will vary by species and age.

For any given turbine design, the continuous variable of total length of the fish at the time to turbine passage is a useful indicator of the likelihood of strike and strike injury/mortality among untested fish species (Table 3).

Intrinsic Sensitivity to a Turbine Passage Stressor - Influence of Integument on the Response to Abrasion

Description of Stressor - As noted for strike, abrasive contact of the entrained fish with hard structures or fluid shearing forces can occur when the fish is moving roughly parallel to the surface, e.g., near a wall and/or highly turbulent fluid boundary layer. While often not as immediately damaging as a direct strike, shearing stresses of thousands of $\mathrm{N} / \mathrm{m}^{2}$ can be produced by submerged jets alone (Čada et al. 1997). Depending on the size and species of fish, such forces can tear tissue (leading to immediate mortality) or abrade (de-scale) the surface of the fish, leading to mortality in the succeeding hours or days from osmotic stresses or infections.

Fish Trait related to Turbine Passage Abrasion: Integument - Fish passing through a turbine may have their body surface abraded by contact with hard structures or by fluid forces (shear stresses and turbulence) created by the high-velocity water flows. At the least, these abrasive forces may remove the protective mucous layer on the fish's body surface, exposing it to osmotic stress and infections. Stronger forces may remove scales, tear the skin, and cause folding and tearing of the operculum. 
Čada et al. (1997) reviewed the limited studies of the effects of shear stresses on fish that had been carried out at the time. Since then, a number of studies have shown that high-velocity-induced shear forces can injure or kill fish (Neitzel et al. 2000, 2004). In large Kaplan turbines, it appears that shear stresses strong enough to kill fish occur in a relatively small region of the turbine, i.e., very close to turbine walls and other hard surfaces (Čada et al. 2006). However, smaller turbines with higher velocity flows may have a greater potential for causing abrasion injuries among turbine-passed fish.

The susceptibility to abrasion injuries is both species and size specific. Turnpenny et al. (1992) observed little effects of shear stresses on eels (which may be resistant because of their thick mucous coating) and high sensitivity among clupeids (whose mucous coating and scales were easily removed). Salmon and trout appeared to be intermediate in their sensitivity to the shear stresses created by high velocity jets of water. Similarly, Neitzel et al. (2000) found a clupeid (American shad, Alosa sapidissima) to be more sensitive to shear stresses than salmonids.

Turbines will differ in their capacity to induce injurious shear stresses. Turbines characterized by high passage velocities, small passageways, and structures that can create localized flow reversals and turbulence will cause more shear stress-related damage to entrained fish than turbines with large passageways that are characterized by slow-moving, non-turbulent flows. For any given turbine design, the type of integument (e.g., hard, bony plates, easily removed scales, or thick slime coating) is a useful indicator of the likelihood of abrasive injuries/mortalities among untested fish species (Table 3).

\section{Fish Population Sustainability}

The loss of individual fish from downstream passage and turbine passage mortality will affect different fish populations to different degrees. Resident fish remaining in the reservoir and headwater streams may be able to compensate for turbine passage losses by increased survival and/or reproduction. Alternatively, these compensatory mechanisms may not be sufficient to prevent a decline in population numbers and subsequent changes in community structure and function. Similarly, downstream passage mortality of individual diadromous/potadromous fish may or may not be detrimental to the overall population or fish community. A species' demographic traits and ability to recolonize areas impacted by turbine passage will influence the population's sustainability in the face of hydropower operations (Table 4; Figure 2).

\section{Fish Population Sustainability - Effects of Demography}

Demographic traits influence the population growth rate, and consequently population densities and age distributions (Rubach et al. 2010). Important demographic traits relevant to fish species that inhabit hydropower reservoirs include life span and natural mortality rates, generation time (the interval between reproductive events), number of reproductive events per year, and the number of offspring per reproductive event. Fish species that have a low natural mortality rates, short generation time, more than one reproductive event per year, and/or produce large numbers of eggs are less likely to experience population level effects from turbine passage losses than are species without these characteristics. 
Table 4. Examples of fish traits that have bearing on reservoir passage and the mechanistic linkage between reservoir passage and fish trait

\begin{tabular}{c|l|l}
\hline \multicolumn{1}{c|}{ Trait } & \multicolumn{1}{c|}{ Definition } & Reservoir Passage Stressor-Trait Linkage \\
\hline Demography & $\begin{array}{l}\text { Characteristics of the population such as } \\
\text { abundance, size structure, life span, } \\
\text { generation time, and mortality rates }\end{array}$ & $\begin{array}{l}\text { Demographic traits influence the ability of } \\
\text { the fish population to recover from losses } \\
\text { of individuals }\end{array}$ \\
\hline Recolonization & $\begin{array}{l}\text { Ability of a fish species to re-occupy an } \\
\text { area by upstream swimming or drifting } \\
\text { downstream }\end{array}$ & $\begin{array}{l}\text { Provision of adequate upstream fish } \\
\text { passage facilities will allow fish to enter } \\
\text { the reservoir from tailwaters. } \\
\text { Downstream drift of individuals from the } \\
\text { main channel, side channels, or tributary } \\
\text { streams will re-populate the reservoir }\end{array}$ \\
\hline
\end{tabular}

Winemiller and Rose (1992) examined life history characteristics of 216 North American fish species and defined three fundamental strategies. Fish species with an opportunistic strategy have a short generation time, high reproductive effort, small body size, low batch fecundity, and low investment per offspring. Fish species with a periodic strategy have long generation times, moderate reproductive effort, large body size, high batch fecundity, and high investment per offspring. Finally, fish exhibiting an equilibrium life history pattern have moderate to long generation time, low reproductive effort, variable body size, low batch fecundity, and high investment per offspring. All else being equal, it might be expected that populations of species with an opportunistic life history strategy might be relatively more resistant to turbine passage mortality (because of their small size) and could better recover from turbine passage losses (because of their short generation time and high reproductive effort). Winemiller (2005) regards the attributes associated with an opportunistic strategy as valuable for colonizing water bodies; these traits are characteristic of inhabitants of marginal disturbed habitats such as ephemeral pools and intermittent streams. On the other hand, many of the characteristics of the equilibrium life history pattern would suggest slow recovery from mortality, including turbine passage; Winemiller and Rose (1992) place salmon and trout in this category.

Noble et al. (2007) categorized European freshwater fishes into longevity categories: long-lived (> 15 years), intermediate life span (5-15 years), and short-lived ( $<5$ years). In addition, they defined early maturation and late maturation as occurring at less than or greater than $25 \%$ of the life span, respectively. Although these categories are a coarse measure of life history strategies, they nonetheless may be useful indicators of the speed with which fish species can recover from turbine passage losses.

The evaluation of longer-term, population level effects of turbine-passage losses among untested fish species can derive considerable insight from their demographic traits, e.g., life span, natural mortality rates, and reproductive strategies (Table 4). 


\section{Fish Population Sustainability - Influence of Recolonization}

The ability of a fish species to maintain a viable population in the face of turbine passage losses is related to its ability to recolonize the hydropower reservoir (Figure 2). Recolonization from below the reservoir may result from effective upstream passage measures, especially in the case of diadromous fish. Recolonization of the reservoir by non-migratory fish can also occur by dispersal from upstream river reaches and tributaries, and is affected by the availability of refugia and the connectivity or fragmentation of the river system (Lake et al. 2007). Rubach et al. (2010) describe other characteristics that influence the rate of dispersal/recolonization into an area affected by stressors; species that are less effective at recolonizing an area include those with a short dispersal distance (often related to body size), an already patchy distribution (less likely to become widely distributed), that exhibit territorial behavior, or that have a passive dispersal mode (e.g., downstream drift in a river basin in which water velocities are slowed by impoundments).

For many fish species, population sustainability in the face of turbine-passage losses may be influenced by the ability of individuals to recolonize the impacted area via upstream passage mitigation measures or by drift from tributaries upstream of the reservoir (Table 4). 


\section{Cluster Analysis of Riverine Fish Species for a Traits-Based Assessment}

As an example of the way untested fish species can be combined into similar categories (i.e., clustered) for the purpose of a traits-based assessment of turbine passage impacts, we queried the FishTraits database for relevant data. FishTraits contains information on more than 100 traits for 809 fish species found in freshwaters of the conterminous United States (Frimpong and Angermeier 2009). The database includes information on four major categories of traits: (1) trophic ecology; (2) body size, reproductive ecology and life history; (3) habitat preferences; and (4) salinity and temperature tolerances. Many of these traits are relevant to carrying out a turbine-passage TBA.

An initial query of the FishTraits database was carried out using habitat preferences as a selection criterion. This step identified a subset of 136 fish species that are commonly associated with large river habitats, and therefore are potentially susceptible to hydropower turbine entrainment and turbinepassage mortality. In a subsequent step, fish species were removed from further analysis if they have a maximum total length smaller than $10 \mathrm{~cm}$. (It should be noted that this maximum total length variable does not represent the lengths of fish that are entrained into turbine intakes, as entrainment often involves smaller individuals, e.g., juveniles of larger fish species).

Following the maximum total length filter, the 94 remaining large river habitat species were grouped based on 9 other biological and ecological traits contained in the Fish Traits database:

- age at maturity ('cost' to species persistence, if individual is lost before reproducing)

- longevity (longer lifespan increases the chance of encountering a hydropower project, and often coincides with low reproductive effort and low fecundity)

- potamodromous life history (migration increases the risk of encounter with hydropower facilities)

- traits describing subsets of preferred habitats: (lowland, upland, montane, moderate currents, and fast currents).

A cluster analysis using the Sorensen (Bray-Curtis) distance measure with flexible beta linking method (McCune and Grace 2002) grouped these 94 species as shown in the Figure 3. In this dendrogram, fish species that have a small distance between them are very similar in terms of the 9 traits used for clustering. Conversely, fish species with a large distance value (objective function) are relatively dissimilar in terms of age at maturity, longevity, life history strategy, and/or habitat preferences.

A subsequent ordination of important traits was performed using nonmetric multidimensional scaling NMDS (similar to principal component analysis, but suitable for non-parametric data as here (McCune and Grace 2002). Most notable was the clustering of species associated with fast currents (Figure 4).

This trait-based grouping of species by means of a cluster analysis allows the identification of fish that may share similar vulnerabilities to turbine passage (the left portion of Figure 2 ) or have similar abilities to sustain their populations in the face of turbine passage losses (right portion of Figure 2). Once entrained in the turbine intake flow, sensitivity to turbine passage stressors (the middle portion of 
BC 94 species 9 traits

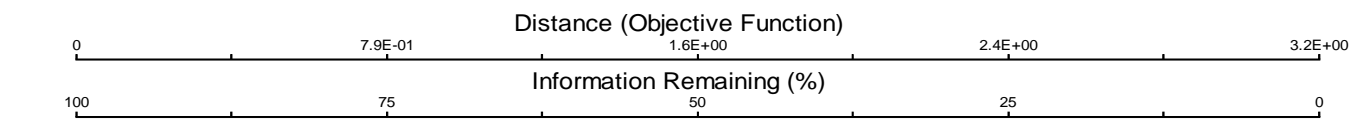

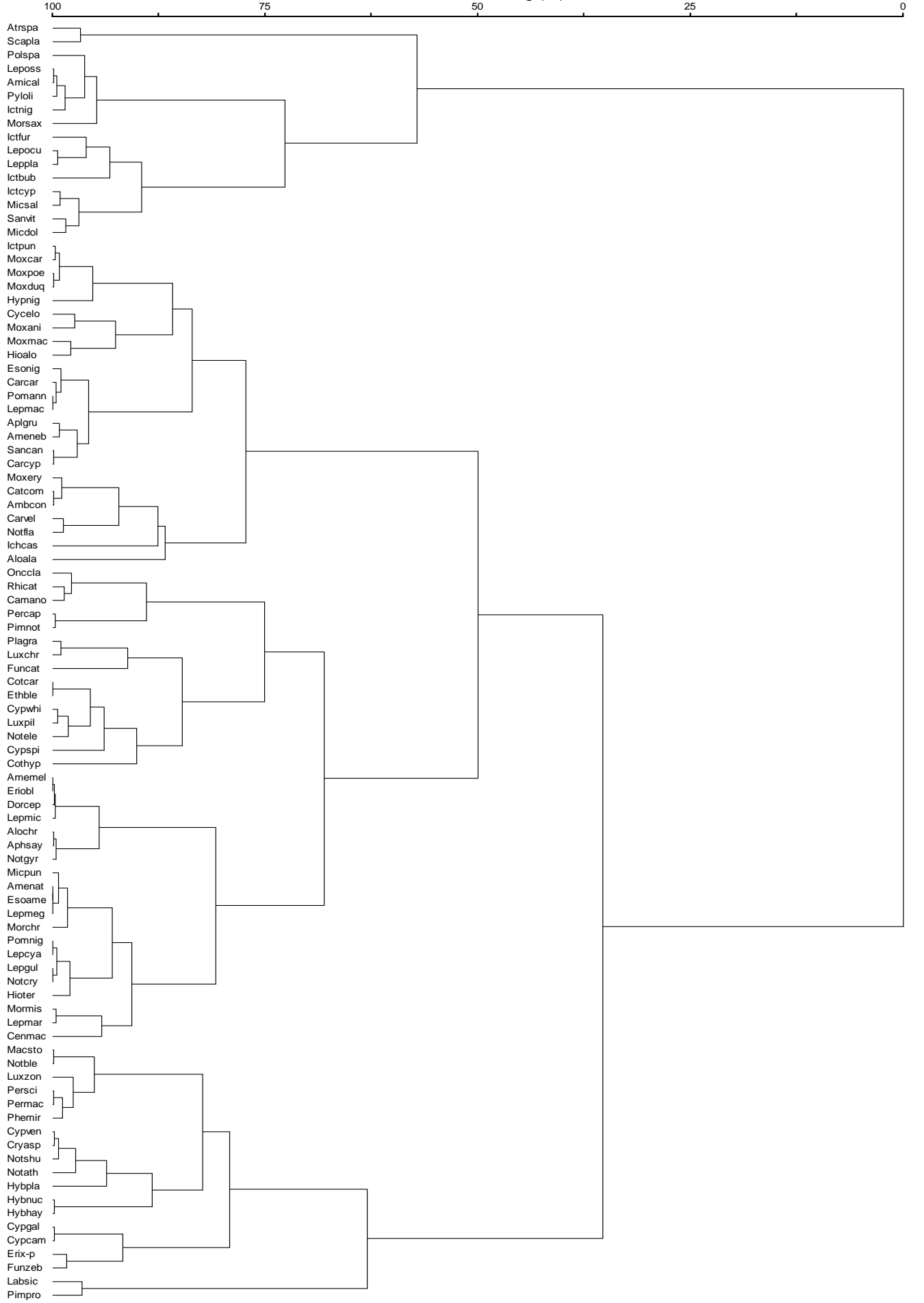

Figure 3. Cluster analysis of 94 freshwater fish species based on 9 traits. 

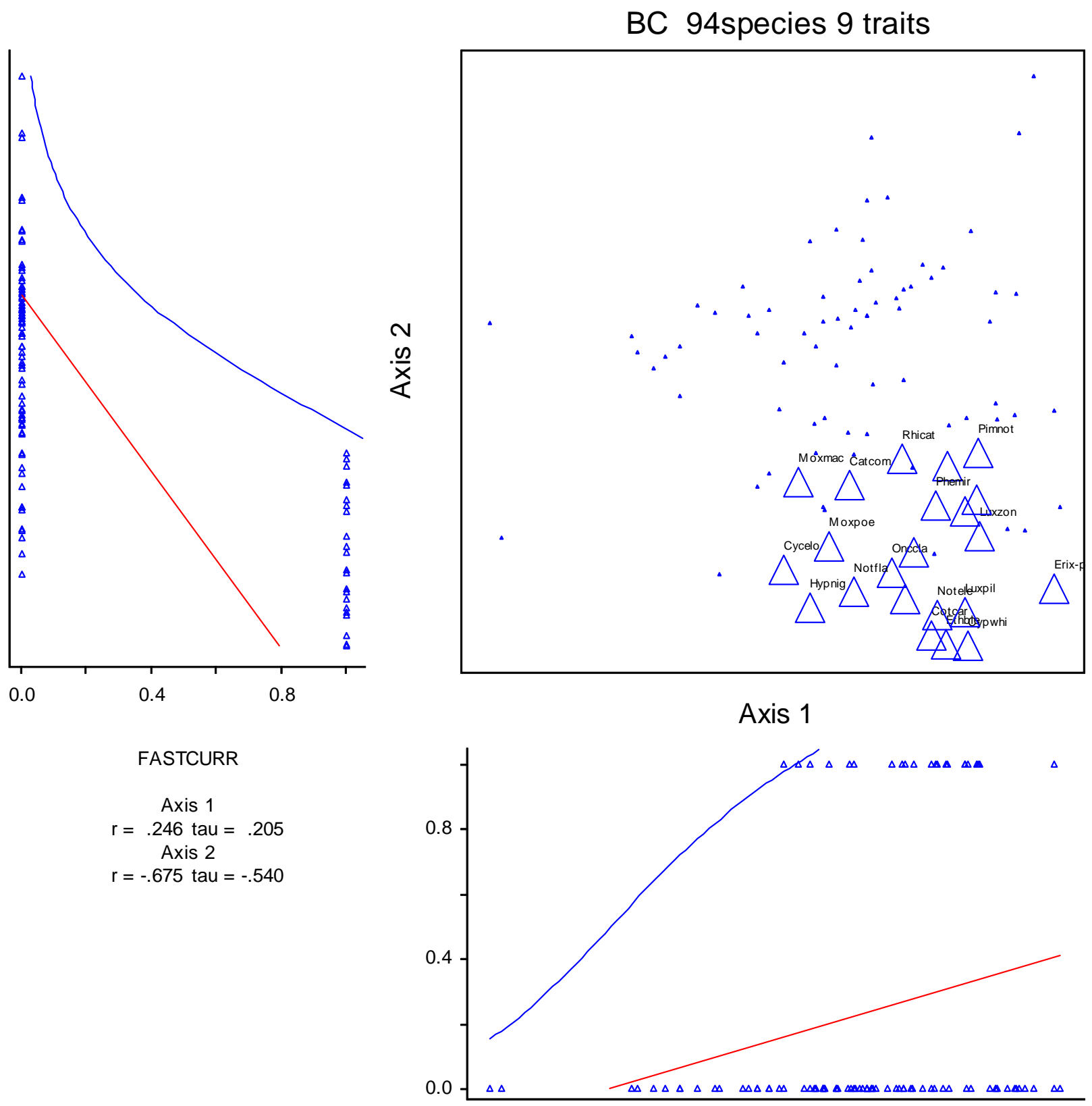

Figure 4. Ordination of 9 traits for 94 species of freshwater fishes using non-metric multidimensional scaling (NMDS). 
Figure 2) would be based on a clustering of different traits, for example, those that describe the morphology of the swim bladder, relative size, and nature of the integument. Characteristics of the turbines that are relevant to defining the performance filters (e.g., pressure changes, rotor blade spacing, severity and locations of turbulent shear stresses) can be quantified and applied via a stressortrait linkage to the subset of fish species that are expected to be entrained. Such an exercise would narrow down the long list of fish species that are present in the river system to a smaller subset of species that are most likely to pass through the turbine and suffer injury or mortality. Turbine passage mortality of this subset of fish can be determined from existing studies or, if needed, representative species can be tested in the laboratory or field. 


\section{Discussion}

It is not possible to quantify turbine passage survival for every species that inhabits or passes through a hydropower reservoir - there may hundreds of species at a particular site. The foregoing discussion suggests that effects of turbine-passage losses of untested fish species could be assessed by a consideration of known species traits such as habitat preferences, life history strategies, behavior, morphology, and demography. Many of the traits discussed in this paper are available in databases for fish species worldwide. Accessing this information could allow the community of fish species near a hydropower site to be categorized as to their susceptibility to turbine passage, their sensitivity to turbine-passage mortality, and the relative ability of their populations to recover from downstream passage losses. Prediction of population vulnerability could be based on mechanistic models of the links between species traits and turbine passage conditions or other hydropower project parameters. The resulting tables of most susceptible and least susceptible species would help focus research, monitoring, and implementation of the most appropriate, effective mitigation measures.

Although TBA focuses on biological and ecological characteristics, taxonomic relationships still have value because of the tendency for closely related species to have similar traits. For example, the presence of a pneumatic duct to rapidly vent gas from the swim bladder is an important trait that reduces a fish's vulnerability to decompression during turbine passage. Because all members of the Family Salmonidae have a pneumatic duct, knowledge of the taxonomic relationship of the fish is a useful determinant of the presence of an important trait. Despite the coincidence of traits with taxonomic relationships, taxonomy alone does not suffice because of the traits may change during the lifetime of an individual; e.g., size and integument are two examples of turbine-passage-relevant traits that vary among different life stages of the same species.

The issues discussed in this report (risk of exposure to turbine passage, sensitivity to turbine passage stresses, and population sustainability in the face of losses) should be considered when evaluating the possible effects of hydropower projects on fish downstream passage and the need for mitigation. Those species that have traits that make their populations relatively vulnerable to reservoir- or turbinepassage effects can be identified, and the appropriate structural and operational mitigation measures can be developed. A downstream passage TBA can contribute to the overall assessment of environmental impacts of new hydropower projects. Further, a TBA can be used to prioritize mitigation measures such as improved flow release regimes to speed the passage of downstream-migrating fish through the reservoir at critical times or the incorporation of advanced turbines to reduce mortality among turbine-passed fish. 


\section{References}

Abernethy, C. S., B. G. Amidan, G. F. and Čada. 2001. Laboratory Studies of the Effects of Pressure and Dissolved Gas Supersaturation on Turbine-Passed Fish. DOE/ID-10853. U.S. Department of Energy, Idaho Falls, ID. 66 p.

ARL (Alden Research Laboratory, Inc.). 1996. Development of a More Fish Tolerant Turbine Runner. Technical Memorandum \#2: Development of Biological Design Criteria. Draft. ARL, Inc., Holden, Massachusetts.

Austen, D. J., P. B. Bayel, and B. W. Menzel. 1994. Importance of the guild concept to fisheries research and management. Fisheries 19:12-20.

Baird, D. J., M. N. Rubach, and P. J. Van den Brink. 2008. Trait-based ecological risk assessment (TERA): The new frontier? Integrated Environmental Assessment and Management 4(1):2-3.

Balon, E. K. 1975. Reproductive guilds of fishes: A proposal and definition. Journal of the Fisheries Research Board of Canada 32:821-864.

Balon, E. K. 1990. Epigenesis of an epigeneticist: The development of some alternative concepts on the early ontogeny and evolution of fishes. Guelph Ichthyology Reviews 1:11-48.

Bell, M. C. 1991. Revised Compendium of the Success of Passage of Small Fish Through Turbines. Report to the U.S. Army Corps of Engineers, North Pacific Division, Portland, Oregon.

Brown, R. S., T. J. Carlson, A. E. Welch, J. R. Stephenson, C. S. Abernethy, D. C. Ebberts, M. J. Langeslay, M. L. Ahmann, D. H. Feil, J. R. Skalski, and R. I. Townsend. 2009. Assessment of barotrauma from rapid decompression of depth-acclimated juvenile Chinook salmon bearing radiotelemetry transmitters. Transactions of the American Fisheries Society 138:1285-1301.

Čada, G. F. 1990. A review of studies related to the effects of propeller-type turbine passage on fish early life stages. North American Journal of Fisheries Management 10(4):418-426.

Čada, G. F., C. C. Coutant, and R. R. Whitney. 1997. Development of biological criteria for the design of advanced hydropower turbines. DOE/ID-10578. U.S. Department of Energy, Idaho Operations Office, Idaho Falls, ID.

Čada, G. F., G. L. Sommers, and M. J. Sale. 2001. What's going on in there? Efforts to describe the experiences of turbine-passed fish. Proceedings of Waterpower XII. Advancing Technology for Sustainable Energy. $\mathrm{HCl}$ Publications, Inc. Kansas City, MO.

Čada, G., J. Loar, L. Garrison, R. Fisher, and D. Neitzel. 2006. Efforts to reduce mortality to hydroelectric turbine-passed fish: Locating and quantifying damaging shear stresses. Environmental Management 37(6):898-006. 
Čada, G. F. and M. C. Richmond. 2011. Can fish morphological characteristics be used to re-design hydroelectric turbines? Proceedings of HydroVision Brazil 2011, September 20-22, 2011. Rio de Janeiro, Brazil. PennWell Publications. $8 \mathrm{p}$.

Culp, J. M., D. G. Armanini, M. J. Dunbar, J. M. Orlofske, N. L. Poff, A. I. Pollard, A. G. Yates, and G. C. Hose, 2010. Incorporating traits in aquatic biomonitoring to enhance causal diagnosis and prediction. Integrated Environmental Assessment and Management, n/a. DOI:10.1002/ieam.128.

de Leeuw, J. J., A. D. Buijse, G. Haidvogl, M. Lapinska, R. Noble, R. Repecka, T. Virbickas, W. Wisniewolski, and C. Wolter. 2007. Challenges in developing fish-based ecological assessment methods for large floodplain rivers. Fisheries Management and Ecology 14:483-494.

Deng, Z., T. J. Carlson, G. R. Ploskey, and M. C. Richmond. 2005. Evaluation of Blade-Strike Models for Estimating the Biological Performance of Large Kaplan Hydro Turbines. PNNL-15370. U.S. Department of Energy, Washington, DC.

Frimpong, E. A. and P. L. Angermeier. 2009. FishTraits: A database of ecological and life-history traits of freshwater fishes of the United States. Fisheries 34(10):487-495.

Froese, R. and D. Pauly, Editors. 2011. FishBase. World Wide Web electronic publication. www.fishbase.org, version (02/2011).

Grift, R. E., A. D. Buijse, and G. J. Van Geest. 2006. The status of limnophilic fish and the need for conservation in floodplains along the lower Rhine River, a large regulated river. Archiv fur Hydrobiologie. 16(4):623-648.

Lake, P. S., N. Bond, and, P. Reich. 2007. Linking ecological theory with stream restoration. Freshwater Biology 52:597-615.

Leonard, P. M. and D. J. Orth. 1988. Use of habitat guilds of fishes to determine instream flow requirements. North American Journal of Fisheries Management 8:399-409.

Magurran, A. E. 2009. Threats to freshwater fish. Science 325(5945):1215-1216.

McCune, B. and J. B. Grace. 2002. Analysis of Ecological Communities. MJM Software Design, Gleneden Beach, OR. $300 \mathrm{p}$.

Monten, E. 1985. Fish and Turbines: Fish Injuries During Passage Through Power Station Turbines. Vattenfall, Stockholm, Sweden. $111 \mathrm{p}$.

Neitzel, D. A., M. C. Richmond, D. D. Dauble, R. P. Mueller, R. A. Moursund, C. S. Abernethy, G. R. Guensch, and G. F. Čada. 2000. Laboratory Studies of the Effects of Shear on Fish: Final Report. DOE/ID-10822. U.S. Department of Energy, Idaho Operations Office, Idaho Falls, ID. 73 p. 
Neitzel, D. A., D. D. Dauble, G. F. Čada, M. C. Richmond, G. R. Guensch, R. P. Mueller, C. S. Abernethy, and B. Amidan. 2004. Survival estimates for juvenile fish subjected to a laboratory-generated shear environment. Transactions of the American Fisheries Society 133:447-454.

Noble, R. A. A., I. G. Cowx, D. Goffaux, and P. Kestemont. 2007. Assessing the health of European rivers using functional ecological guilds of fish communities: Standardising species classification and approaches to metric selection. Fisheries Management and Ecology 14:381-392.

Poff, N. L., M. I. Pyne, B. P. Bledsoe, C. C. Cuhaciyan, and D. M. Carlisle. 2010. Developing linkages between species traits and multiscaled environmental variation to explore vulnerability of stream benthic communities to climate change. Journal of the North American Benthological Society 29(4):1441-1458.

Rubach, M. N., R. Ashauer, D. B. Buchwalter, H. J. De Lange, M. Hamer, T. G. Preuss, K. Topke, and, S. J. Maund. 2010. Framework for traits-based assessment in ecotoxicology. Integrated Environmental Assessment and Management. p. 1-15.

Turnpenny, A. W. H., M. H. Davis, J. M. Fleming, and J. K. Davies. 1992. Experimental Studies Relating to the Passage of Fish and Shrimps Through Tidal Power Turbines. Marine and Freshwater Biology Unit, National Power, Fawley, Southampton, Hampshire, England.

Viana, E. M. F., F. Luiz, H. A. Santos, L. G. M. Silva, and C. B. Martinez. 2011. Turbulent kinetic energy variation influenced by the declivity in the tanks of a fish ladder. Proceedings of HydroVision Brazil 2011, Rio de Janeiro, Brazil, September 20-22, 2011. 6 p.

Vieira, N. K., N. R. Poff, D. M. Carlisle, S. R. Moulton II, M. L. Koski, and B.C. Kondratieff. 2006. A database of lotic invertebrate traits for North America. U.S. Geological Survey Data Series 187. von Raben, K. 1957. Zur frage der beschädigung von fischen durch turbinen. Die Wasserwirtschaft 4:97-100 (Fisheries Research Board of Canada Translation Series 448).

Watson, M. 1995. Allowable gas supersaturation for fish passing hydroelectric dams. Project No. 93-8. Draft Final Report for Bonneville Power Administration, U.S. Department of Energy, Portland, OR. 107 p. + appendices.

Webb, C. T., J. A. Hoeting, G. M. Ames, M. I. Pyne, and N. L. Poff. 2010. A structured and dynamic framework to advance traits-based theory and prediction in ecology. Ecology Letters (2010) 13:267-283.

Welcomme, R. L., K. O. Winemiller, and I. G. Cowx. 2006. Fish environmental guilds as a tool for assessment of ecological condition of rivers. River Research and Applications 22:377-396.

Winchell, F., S. Amaral, and D. Dixon. 2000. Hydroelectric turbine entrainment and survival database: an alternative to field studies. Proceedings of Hydrovision 2000: New Realities, New Responses. $\mathrm{HCl}$ Publications, Kansas City, MO. 
Winemiller, K. O. 2005. Life history strategies, population regulation, and implications for fisheries management. Canadian Journal of Fisheries and Aquatic Sciences 62: 872-885.

Winemiller, K. O. and K. A Rose. 1992. Patterns of life history diversification in North American Fishes: Implications for population regulation. Canadian Journal of Fisheries and Aquatic Sciences 49: 21962218. 